\title{
Careful Commitments: Democratic States and Alliance Design
}

\author{
Daina Chiba, University of Essex \\ Jesse C. Johnson, University of Kentucky \\ Brett Ashley Leeds, Rice University
}

Evidence suggests that leaders of democratic states experience high costs from violating past commitments. We argue that because democratic leaders foresee the costs of violation, they are careful to design agreements they expect to have a high probability of fulfilling. This may cause democratic leaders to prefer flexible or limited commitments. We evaluate our argument by analyzing the design of alliance treaties signed by countries of the world between 1815 and 2003. We find that alliances formed among democratic states are more likely to include obligations for future consultation rather than precommitting leaders to active conflict, and defense pacts formed among democratic states are more likely to specify limits to the conditions under which member states must join their partners in conflict. This research suggests that separating screening effects and constraining effects of international agreements is even more difficult than previously believed. States with the greatest likelihood of being constrained are more carefully screened.

A defining feature of democratic institutions is the relative ease with which citizens can punish leaders for their decisions. If citizens are unhappy with the performance of their leader, they can remove him or her from office through elections or other mechanisms. Recently, scholars have used this aspect of democratic institutions to argue that democratic leaders are more likely to fulfill international commitments (McGillivray and Smith 2008). Citizens concerned with their state's reputation for fulfilling past commitments will be less likely to reelect a leader that violates international commitments, thus providing incentives for democratic leaders to honor their international promises. A number of studies have provided empirical support for the claim that democratic leaders are less likely to violate international commitments (e.g., Gaubatz 1996; Kelley 2007; Leeds 2003a; Morrow 2007).

While the propensity for democratic leaders to fulfill the commitments they make follows from the claim that democratic leaders face high domestic costs for violating agreements, we suggest there are other, prior implications worth considering. If democratic leaders anticipate these high costs of violation, they should be more careful about the commitments they make. Democratic leaders should only make commitments they expect to have a high probability of fulfilling (e.g., Leeds 1999).

We examine this argument in the context of military alliances. We argue that because democratic leaders face high costs from violating commitments, they will sometimes design

Daina Chiba (dchiba@essex.ac.uk) is a lecturer in the department of government at University of Essex, Colchester CO4 3SQ, UK. Jesse C. Johnson (j.johnson@uky.edu) is an assistant professor of political science at University of Kentucky, Lexington, KY 40506. Brett Ashley Leeds (leeds@rice.edu) is a professor of political science at Rice University, Houston, TX 77005.

Data and supporting materials necessary to reproduce the numerical results in the paper are available in the JOP Dataverse (https://dataverse.harvard.edu /dataverse/jop). Previous versions of this manuscript were presented at the Annual Meeting of the Peace Science Society, Knoxville, Tennessee, October 25-26, 2013, the Annual Meeting of the Midwest Political Science Association, Chicago, Illinois, April 11-14, 2013, and at seminars at Vanderbilt University, University of Buffalo, Northern Illinois University, University of Wisconsin-Madison, University of California, Berkeley, Washington University-St. Louis, and University of Essex. The authors' names are listed in alphabetical order; they view their contributions as equal. An online appendix with supplementary material is available at http://dx.doi.org/10.1086/682074.

The Journal of Politics, volume 77, number 4. Published online July 13, 2015. http://dx.doi.org/10.1086/682074

(C) 2015 by the Southern Political Science Association. All rights reserved. 0022-3816/2015/7704-0007\$10.00 
alliance agreements that provide them flexibility to choose their actions at a later date. This allows them to avoid the high costs associated with alliance violation if they are unwilling to assist their partner(s) in the event of military conflict. Additionally, we argue that if democratic leaders do commit themselves to the defense of their partner(s), then they may limit their commitments such that they are required to intervene only under specific conditions. This limits their commitments to circumstances in which they feel confident they will be willing to join a war and minimizes the chance that they will suffer the costs associated with alliance violation. We test the argument using a sample of alliances signed between 1815 and 2003. The analysis reveals strong support for our argument and provides at least a partial answer for an enduring puzzle in alliance politics - the prevalence of half-hearted commitments.

Our argument also has important general implications for studying the effects of international agreements on foreign policy behavior and outcomes. Scholars have previously questioned whether international agreements can constrain state behavior-that is, cause states to behave in ways commensurate with the agreement even when their present interests might cause them to prefer to violate their past promises-or whether the main effect of international agreements is to indicate to others which states have interests in line with the requirements of an agreement (a screening effect). Our argument and results suggest that those states that are most likely to be constrained by agreements screen more carefully; screening is endogenous to constraint. This suggests that constraint may be more difficult to observe, but it also suggests that agreements should serve as a more effective signal of future intentions for states believed to be more effectively constrained by agreements.

\section{DESIGNING ALLIANCES WITH DOMESTIC AUDIENCES}

Military alliances are formal agreements signed by leaders of independent states that commit the leaders to cooperate in the event of future military conflict. The dominant scholarly view is that state leaders sign alliances for the benefits of signaling and commitment. First, the fact that states are willing to bear the costs of formalizing the commitment provides information to adversaries and allies about their interests and probable future behavior. Second, the coordination benefits and potential reputational costs generated by the agreement may change the incentives of states, making it more likely that they will fight together in future conflicts (Fearon 1997; Morrow 1994; Smith 1995, 1998a).

The signaling and commitment generated by formalizing alliances is intended to deter adversaries. When a state leader is considering making a demand of another state backed by the threat of military force, the primary factor influencing the leader's decision about whether to make a demand and what demand to make is the leader's expectation about his or her state's ability to prevail should war occur. Potential targets who receive assistance from outside powers are, all else equal, more difficult to defeat in conflict. Thus, to the extent that formal alliances are useful indicators of whether a potential target will receive assistance in conflict, states with allies should be less likely to be the targets of militarized disputes. Formal models and empirical evidence both suggest this to be the case (Johnson and Leeds 2011; Leeds 2003b; Morrow 1994; Smith 1995, 1998a).

The deterrent potential of alliances should be related to the clarity and strength of the commitment made. Unambiguous promises of active military support increase the likelihood that members will experience costs for failing to intervene in a conflict on behalf of an ally. Commitments that are more costly to break should in turn be more credible to potential challengers. Thus, strong and clear commitments should deter a greater range of potential challengers. In addition, commitments that include a broader range of conditions (that is, are invoked under a wide range of circumstances) have the potential to deter a larger set of potential challengers than those alliances that are limited, for instance, to particular adversaries, locations, or ongoing conflicts. Given the uncertainty that exists about future threats, states should prefer commitments that are applicable to any future challenge.

This logic, as Fearon (1997) points out, creates a puzzle. In fact, partial commitments exist. Many alliance agreements do not require states to precommit to assist one another militarily but instead obligate the states to consult in the event of military crisis with the goal of formulating a coordinated response. These consultation pacts provide a clear indication to adversaries that the states expect to share at least some common interests and hope to work together in response to any crisis, but they stop short of guaranteeing assistance. The latter fact should not escape notice by adversaries; adversaries should doubt the credibility of the coordination promise given that the states were unwilling to precommit themselves to joint action. Yet consultation pacts are common. According to the Alliance Treaty Obligations and Provisions (ATOP) data set, $32 \%$ of the alliances signed between 1815 and 2003 that require military coordination versus an adversary include only promises to consult and attempt to coordinate future behavior (Leeds et al. 2002). ${ }^{1}$

Consider, for instance, the language in the 1912 consultation pact between Great Britain and France (Baltzly and

1. This calculation excludes agreements that include only promises of nonaggression from the denominator. We allow consultation pacts to provide for promises of nonaggression, but not for promises of neutrality or active military support. 
Salomone 1950, 37-38). On one hand, this agreement explicitly states that the governments have not precommitted themselves to joint action; the text makes quite clear that choosing to stay out of a future conflict involving the ally would not be considered a violation of the agreement. On the other hand, the agreement also makes it clear that the military staffs have and will continue to make plans for joint action should it be necessary, and should conflict occur, they will immediately consider the possibility of fighting together. Thus, the agreement should cause adversaries to anticipate the possibility of joint action but should make them less confident of intervention than a full commitment to act together militarily would. At the same time, the flexibility this agreement provides in determining future actions lowers the risks that a state will experience costs associated with violating a commitment.

It is also common for state leaders to limit their commitments to provide active military assistance to particular circumstances, for instance, conflict with a particular adversary or conflict in a particular location. Forty-five percent of defense pacts in the ATOP data set specify that the obligations are invoked only under specified circumstances (Leeds et al. 2002). The United States, for example, limited its active military obligations within the Southeast Asian Collective Defense Treaty (SEATO) to "communist aggression" (United Nations 1955, Treaty no. 2819). This provision ensured that the United States would be committing itself only to defend its partners in cases in which US leaders foresaw very strong US interests in war participation and would not, for instance, be obligated to assist Pakistan in a war against India. Such provisions limit obligations (and the risk of violation) at a cost to deterrence.

One possibility is that more flexible or limited commitments are favored because state leaders recognize that their alliance design decisions influence two audiences-the adversary and the ally (Benson 2012; Kim 2011). Many scholars have suggested that there is a trade-off between deterring an adversary and emboldening a partner. Strong commitments that do more to convince a potential adversary that an ally will assist a target may also give that target the confidence to take a tough stand, or even to engage in bellicose actions. Thus, Snyder suggests that states try to manage the trade-off between what he calls abandonment and entrapment (1984, 1997). Kim (2011) argues that states with sufficient bargaining power will be able to limit the possibility that they are drawn into conflicts that they prefer not to fight by their partners' bellicose behavior through precisely specifying the conditions under which the alliance treaty is activated. Benson (2012) argues instead that leaders concerned about entrapment will be motivated to form alliances with ambiguous commitments, leaving themselves sufficient freedom of action to stay out of conflicts later. By making their commitments "probabilistic," leaders may be able to create enough uncertainty to appropriately balance deterring an adversary with not emboldening a partner. ${ }^{2}$

Yet one might wonder why a state would ever be able to be entrapped by a partner with differing interests. States have a choice whether to join a war, and, in fact, an ally's threat not to intervene under conditions in which the target should concede should serve to restrain the target from taking such tough bargaining stances (Fang, Johnson, and Leeds 2014; Snyder 1997). The only way an ally can be entrapped is if the leader cannot credibly abandon the target due to high costs to alliance violation (Fang et al. 2014). Thus, the risk of entrapment is closely related to the costs a state expects from violating a given alliance commitment.

Where do costs from alliance violation come from? First, there are costs associated with the value of the alliance. For instance, the state may value the assistance of the alliance partner in other conflicts. Perhaps the state faces multiple potential adversaries, and not joining the target in one conflict might prevent the target from joining the ally in another conflict. The state might also fear that not fulfilling the alliance will jeopardize other important foreign policy concerns by damaging relations with the ally; if the state gets trade benefits or foreign aid or support for other foreign policy priorities in return for the security promise, breaking the alliance could have costs in other areas (e.g., Morrow 1991). In these cases, a strong alliance is important to the state in question, and limiting the effectiveness of the alliance in order to mitigate the risk of entrapment may not be a desirable strategy.

Second, however, there are costs to a state's or a leader's reputation. Gibler (2008) and Crescenzi et al. (2012) show that states that have previously violated alliances are less likely to be able to form new alliances. A substantial literature also suggests that some leaders may expect significant domestic costs from violating a past commitment. Leaders who expect particularly high costs from violating past commitments may be willing to trade off deterrence effectiveness to mitigate the risk that they will experience costs of violation; they may find flexible and/or limited commitments particularly desirable. Benson's (2012) and Kim's (2011) arguments may be especially applicable to states that experi-

2. While Benson's analysis focuses on differences in the language within defense and offense pacts, we argue that a classic example of a flexible commitment is the consultation pact. Benson codes 45 of 260 defense pacts as "probabilistic." We test our hypotheses using this operationalization of flexible commitments also. The results are presented in the appendix, table A.2, and provide additional support for our argument. 
ence high audience costs (international and/or domestic) from violating commitments.

Citizens of states have reason to be concerned about state reputations for keeping promises and fulfilling threats. As a result, when leaders jeopardize that reputation, citizens have incentives to remove them in favor of new leaders with greater international credibility. Because removing leaders in states with democratic institutions entails fewer costs and risks to citizens, having sullied a state's reputation has a greater likelihood of having negative consequences for a leader's ability to stay in power in a democratic state than in a nondemocratic state (McGillivray and Smith 2008). Scholars have used this logic to argue that democracies are more likely to make credible threats and to fulfill their international commitments (e.g., Fearon 1994; Leeds 1999; Schultz 1999; Smith 1998b).

The fact that democratic leaders expect to be bound to their international commitments by the threat of domestic punishment may in some cases make leaders wary of forming risky international agreements (Leeds 1999). For example, while there is some evidence that democratic states tend to be particularly open to conflict mediation (Dixon 1993), Simmons (2002), and Gent and Shannon (2011) do not find that democracies are more willing to commit to modes of conflict resolution that produce binding agreements, for example, arbitration and adjudication. ${ }^{3}$ Similarly, Mitchell and Hensel (2007) find that jointly democratic dyads are less likely to reach an agreement to settle contentious issues during any given round of negotiations, and they attribute this to the wariness democratic leaders have in making commitments to agreements that might later fail.

While in some cases democracies may avoid commitment altogether, in other cases democratic leaders may work to design agreements that mitigate the risks that they will experience the domestic costs associated with agreement violation later. For example, Rosendorff and Milner (2001) argue that when state leaders have uncertainty about their future interests, they may include escape clauses in their international agreements to allow them to defect without experiencing punishment. Koremenos (2005) argues that uncertainty about future interests can cause leaders to form agreements with short durations, again allowing themselves a legal way to extricate themselves from a past commitment. And Hafner-Burton, Helfer, and Fariss (2011) find that democracies are more likely to take advantage of the right to derogation in human rights

3. Allee and Huth (2006) find that jointly democratic dyads are more likely to pursue legal settlement than make bilateral concessions, but they are not more likely to pursue legal settlement rather than continuing a stalemate. treaties. In each of these cases, leaders choose to create agreements with less depth and obligation, potentially limiting their gains from cooperation, in order to avoid being locked into an agreement at a future date.

While one strategy for leaders who fear the future costs of violation might be to increase the flexibility of their commitments under conditions of uncertainty, another strategy might be to limit the degree of uncertainty regarding the conditions under which they will be required to act. ${ }^{4}$ If leaders are specific about the circumstances under which action is required by an agreement, they limit the probability that they will be in the position of violating the commitment in the future by limiting their obligations to circumstances in which they have high expectations that they will be willing to act. Thus, under conditions in which democratic states are confident that they would be willing to fulfill agreements under some circumstances, they may choose limited commitments, whereas under conditions of greater uncertainty, they may choose flexible commitments.

The attraction of flexible alliance commitments to a democratic leader stems from two competing pressures that will arise in the future if the agreement is invoked. On one hand, we have evidence that democratic publics prefer for their leaders to uphold their international legal commitments (Tomz 2008). Recent experimental evidence suggests that citizens are much more favorably disposed to military action to support an ally than a non-ally, and survey respondents explain their support based on their commitment to fulfilling alliance promises (Tomz and Weeks 2015). On the other hand, going back as far as Kant, many scholars have claimed that the public dislikes war and plays a role in restraining bellicose leaders in democracies. This suggests that a leader who faces the responsibility of either supporting a partner in war or breaking an alliance is in a tough position; either action could have negative consequences for the leader's ability to maintain power (e.g., Croco 2011). McGillivray and Smith (2008) explain that even if a democratic public gets a better payoff by breaking a past agreement and thus prefers for the leader not to fulfill the commitment in the present, the public also benefits from removing that leader from office once the leader has hurt the state's reputation in the hope that a new leader would be better trusted internationally. Thus,

4. The uncertainty we are referring to is uncertainty about the state's future international interests, not about the preferences of future leaders of their own state. Some scholars have alternatively argued that democratic leaders who prefer international cooperation and fear they will lose power to a domestic opponent with different foreign policy preferences will be particularly likely to choose strong commitments that their domestic successors will find it harder to break (e.g., Mattes 2012; Moravscik 2000). 
even those publics who prefer to break an alliance rather than fight might still prefer to replace the leader who violated the international commitment. Our argument is that leaders try not to put themselves in such a difficult position by being especially careful about the commitments they make, perhaps erring toward the side of caution even at the cost of limiting deterrence.

We do not expect that most members of the public have detailed knowledge of the language included in alliance agreements. Yet at the time a situation arises that might invoke an alliance, the language of the alliance (and how obligations are framed by elites) will become quite salient. What matters for leader survival is whether domestic political opponents can be successful in framing the situation as one in which the leader has risked the national honor by putting the state's reputation at risk and abandoning an ally in its time of need, and this in turn should be influenced by the actual promises made. Thus, leaders may well compromise deterrence in order to limit the possibility that they will be held accountable for violation at a later date. ${ }^{5}$

Our logic suggests that leaders should be concerned about making commitments that they will later be called upon to fulfill. Yet many democratic leaders do not stay in office for long periods, and given their short time horizons, leaders might worry less about alliance commitments that might be invoked at a date further into the future. In democratic systems, however, treaty formation involves more actors than just the chief executive. The leader's legislative coalition must agree to ratify the treaty. This coalition is made up of ambitious politicians, many of whom may envision themselves as future leaders. Even if the democratic leader herself may not be in power when an alliance is invoked, her party and coalition members hope to be. They may pressure a leader to make flexible or limited commitments.

Thus, leaders operating in democratic states may expect domestic costs for failing to fulfill an alliance commitment, and this in turn may make it more difficult for democratic leaders to restrain their allies because they have a less credible threat to abandon an intransigent partner. In order to avoid violation or entrapment, leaders of democratic states may sometimes limit the depth and obligations of their alliances by making their commitments flexible and/or limited. We are not arguing that nondemocratic states never worry about the costs of breaking alliances. As we state above, there are international reputational consequences for breaking al-

5. Similarly, Snyder and Borghard (2011) argue that state leaders tend to make threats that are ambiguous enough to allow leaders the future flexibility to back down without experiencing audience costs. liances as well. We also do not argue that nondemocratic leaders have no domestic audience nor that the domestic audience of nondemocratic leaders is uninterested in a reputation for fulfilling commitments. Instead, we argue that because leaders in democratic states can be removed from office at lower cost, they are more likely to face the consequence of losing office as a result of violating an international commitment (McGillivray and Smith 2008). ${ }^{6}$ All else equal, leaders of democratic states will be more willing than their nondemocratic counterparts to forgo the greater deterrence offered by a firmer or broader commitment in order to avoid the potential costs associated with violating a commitment. Once they have decided to form an alliance, leaders operating in democratic states may be more likely to choose consultation pacts over defense pacts and to limit the conditions under which their defense pacts are applicable.

Studying alliance design presents a research design challenge, however. We only observe alliance designs that are acceptable to all members of the alliance. We generally do not have data for a large number of cases about the designs individual members or potential members preferred during negotiation. While our theory concerns the alliance designs that might be preferred by particular kinds of states, we can only observe alliance designs that are jointly acceptable to all state members. A number of factors may affect the bargaining power of different actors during the design process. While we do not model these factors explicitly, we hypothesize that as the proportion of original alliance members that are democratic increases, the alliance design should be more likely to reflect the preferences of democratic members. $^{7}$ This is both because the democratic members should have more bargaining influence as their numbers increase and because democratic potential members may be less likely to sign the final alliance if the design is against their preferences, leading to the observation of fewer democracies in those alliances.

6. There is variance in the extent to which nondemocratic leaders experience audience costs, but leaders in democracies experience higher costs than leaders in nondemocracies on average (e.g., Mattes and Rodriguez 2014; Uzonyi, Souva, and Golder 2012; Weeks 2008).

7. An alternative approach would be to argue that final design should reflect the most conservative member's preferences, and thus the inclusion of even one democratic state in the alliance should result in a higher probability of commitments being more flexible and/or specific. Because there are other dimensions on which bargaining power varies, we are less confident suggesting that one democracy would always be decisive in design. As a robustness test, however, we do evaluate the effects of having any democratic members. We find continued support for hypothesis 1 using this alternative operationalization, but weaker support for hypothesis 2. See tables A.3 and A.4 in the appendix. 
Specifically, our hypotheses are:

H1. Alliances formed by a larger proportion of democracies are more likely to obligate states to future consultation rather than active assistance.

H2. Defense pacts formed by a larger proportion of democracies are more likely to specify limits to the conditions under which defensive obligations are invoked.

In the next section, we describe our research design for evaluating these hypotheses, and in the following section, we discuss our empirical results. We follow with a discussion of the implications of our findings for broader questions about the effects of international agreements on behavior.

\section{RESEARCH DESIGN}

In order to test these hypotheses, we analyze treaty obligations of all alliance agreements collected by the ATOP project, with the exception of pure nonaggression pacts (Leeds et al. 2002). ${ }^{8}$ The data span the time frame from 1815 through 2003 and include 536 alliance agreements. ${ }^{9}$ Our unit of analysis is a newly formed alliance. ${ }^{10}$

We use two dichotomous dependent variables to test the two hypotheses. Our first dependent variable measures whether or not an alliance agreement obligates the member states to future consultation rather than precommitting them to join their partners in war or remain neutral..$^{11}$ In order to be included in the ATOP data set, a consultation

8. We exclude agreements that commit the states to nonaggression and have no obligations for defensive support, offensive support, neutrality, or consultation because they resemble conflict management agreements much more than alliances (Leeds and Mattes 2007; Mattes and Vonnahme 2010). We use ATOP version 3.0.

9. In a set of additional analyses we examine whether our results are driven by Cold War politics. We estimate models that drop NATO from the sample, include a Cold War dummy variable, drop the alliances formed during the Cold War, include a US dummy variable, and drop alliances formed with the United States. We find support for both hypotheses with all of these different model specifications. See tables A.5 through A.10 in the appendix.

10. In some cases, the obligations of alliances are modified after their formation. We analyze only the initial design with two exceptions. There are two alliances that are initially formed as nonaggression pacts but later are modified to include additional obligations. In these two instances (ATOP IDs 4810 and 4985) we code phase 2 of the alliance as its formation since it would not be in our sample based on phase 1 . The results are not sensitive to dropping those alliances. See tables A.11 and A.12 in the appendix.

11. As a robustness check, we also analyze a variable in which we allow consultation pacts to include neutrality obligations and distinguish these from agreements that require active participation in conflict or neutrality without consultation obligations. For this version of the vari- pact must specifically require the member states to consult in the event of crises that have the potential to involve military conflict and attempt to pursue a coordinated response (Leeds 2005, 10). This variable takes on a value of 1 for an alliance that only obligates states to future consultation but not to any form of military assistance, and 0 otherwise. It is coded as 1 for 171 cases (32\%).

Our second dependent variable measures whether or not a defense pact specifies limits to the conditions under which defensive obligations are invoked. This variable is defined only for the subset of alliance agreements that have defensive obligations. Alliances might specify that the defensive obligations are only invoked if a member is attacked by a specific adversary, or in a specific location, or without provocation by the ally (see Leeds and Mattes 2007, 192). The variable takes on a value of 1 for any alliance including defensive obligations that specifies any limits to the conditions under which defensive obligations are invoked, and a value of 0 for any alliance including defensive obligations that does not specify such limits. There are 260 alliance treaties that have defensive obligations, and this variable is coded 1 for 116 cases (45\%).

We measure our primary independent variable, the proportion of democracies in the alliance, using information from the Polity IV project (Marshall, Jaggers, and Gurr 2012) and the regime type data set published by Cheibub, Gandhi, and Vreeland (2010). This variable is operationalized as the proportion of alliance members that are democracies at the time of alliance formation. We code this variable based on the original members of the alliance, since only original members should influence alliance design. The variable ranges from 0 (cases with no democratic members at formation) to 1 (cases in which all alliance members are democracies at the time of alliance formation).

A country is coded as a democracy if it receives a polity2 score of 6 or higher in the year of alliance formation (Marshall et al. 2012). There are some countries that lack a polity2 score for the year in which they formed an alliance. In some cases, this is because the state formed the alliance less than one year before it became officially independent. In these cases (e.g., Czech Republic in 1992), we base our democracy coding on the polity2 score from the following year. In other cases, however, the state is not included

able, 218 cases are coded 1 (41\%). We also estimate a model dropping 44 alliances that include neutrality obligations but not defense, offense, or consultation obligations. This allows us to compare consultation pacts only to pacts requiring active participation in military conflict. In both cases, the interpretation of results is similar. See tables A.13 and A.14 in the appendix. 
in the Polity IV data set at all or is missing for several years in a row. For cases after 1945 that are not included in Polity IV, we code a state-year as democratic if the state is coded as a democracy by Cheibub et al. (2010). For five cases (all German states during the period of German Confederation), we code regime type based on other secondary sources. The remaining cases are states that formed an alliance while they were under occupation by another country (specifically, Belgium, the Netherlands, Luxembourg, and Norway in 1942). We drop these cases from both the numerator and denominator of our measure since we do not feel comfortable coding the regime type of the governments in exile. ${ }^{12}$

Figure 1 shows the distribution of our key independent variable, proportion of democracies at the time of alliance formation, for the two samples analyzed. The panel on the left shows the distribution of this variable for the sample used to evaluate hypothesis 1, all alliances formed between 1815 and 2003. Most alliances are formed among nondemocracies (51\%). In $26 \%$ of the observations, half of the original alliance members were democracies. Many of these observations are alliances in which a democracy and a nondemocracy formed a bilateral alliance. The third most populous category is alliances in which all the member states are democratic at the time of alliance formation (16\%). The panel on the right shows the distribution for the variable for the subset of alliances with defense obligations. The modal category is again alliances with no democratic members at the time of formation, followed by the category in which $50 \%$ of the original members are democratic, and then followed by alliances formed by exclusively democratic members. These three categories make up approximately $92 \%$ of the observations with defense obligations.

In order to be certain that the relationships we observe between our primary independent variable and our dependent variables are not spurious relationships driven by another factor related to both alliance design and the proportion of democratic alliance members, we also present models in which we control for factors that we expect might play a role in explaining the dependent variable and could be correlated with our primary independent variable. Some of these factors reflect the environment that the member states are

12. The polity 2 score is missing for $3.8 \%$ of the country-years in our data set. We describe our democracy coding for the countries missing polity 2 scores in table A.1 of the appendix. If we limit our analysis to cases in which the polity 2 score is available and treat other cases as missing, our interpretation of results remains unchanged. See tables A.15 and A.16 in the appendix. Dropping occupied states affects only one alliance in our data set, ATOP ID 2550. Our results are unchanged if we remove that alliance from the analysis. See tables A.17 and A.18 in the appendix. facing at the time they form the alliance, and some reflect other design decisions.

In our analysis of consultation obligations we include four control variables. First, we control for the similarity of interests among the alliance members. When states believe they have more foreign policy interests in common, they may expect their future incentives to be more in line as well and may worry less about making stronger alliance commitments. Similarity of interests should thus be negatively related to the probability states form a consultation pact rather than a pact explicitly requiring active assistance. We measure similarity of interests using the S-score of Signorino and Ritter (1999) based on networks of alliance commitments, but we create the S-score using ATOP alliance data, a process that is fully explained in our online appendix. We calculate the S-score one day before alliance formation to make sure that the score is not influenced by the formation of the alliance in question. We then take a weak link approach, measuring similarity of interests among alliance members as the minimum S-score of any pair of original alliance members. Our results are also robust to a measure that utilizes the mean S-score of pairs of states within an alliance at the time of formation (see tables A.19 and A.20 in the appendix).

Second, we control for the number of members within an alliance. Proponents of international cooperation may sometimes face a broader-deeper trade-off; increasing membership in cooperative agreements may involve watering down commitments to the point that they become acceptable to a larger range of states. Thus, alliances with larger memberships may be more likely to be limited to consultation. Information about membership also comes from the ATOP data set.

Third, we control for the level of threat faced by alliance members. As states feel more threatened, they are more likely to choose a defense pact rather than a consultation pact to obtain the benefits of greater deterrence. We measure the level of threat faced by each member state during the year the alliance is formed using the formula of Leeds and Savun (2007), which takes into account both the capabilities and similarity of interests of states within a given state's politically relevant international environment. ${ }^{13} \mathrm{We}$ again assume the weak link approach and measure the threat

13. There are two differences between our measure and Leeds and Savun's (2007). First, in constructing our measure we rely on our S-score created using the ATOP alliance data, discussed in the appendix. Second, we only consider State B a possible threat to State A if State B is contiguous to State A or a major power. In the Leeds and Savun (2007) measure, minor powers who were not contiguous were considered possible threats to major powers since they are part of the major power state's politically relevant international environment. 


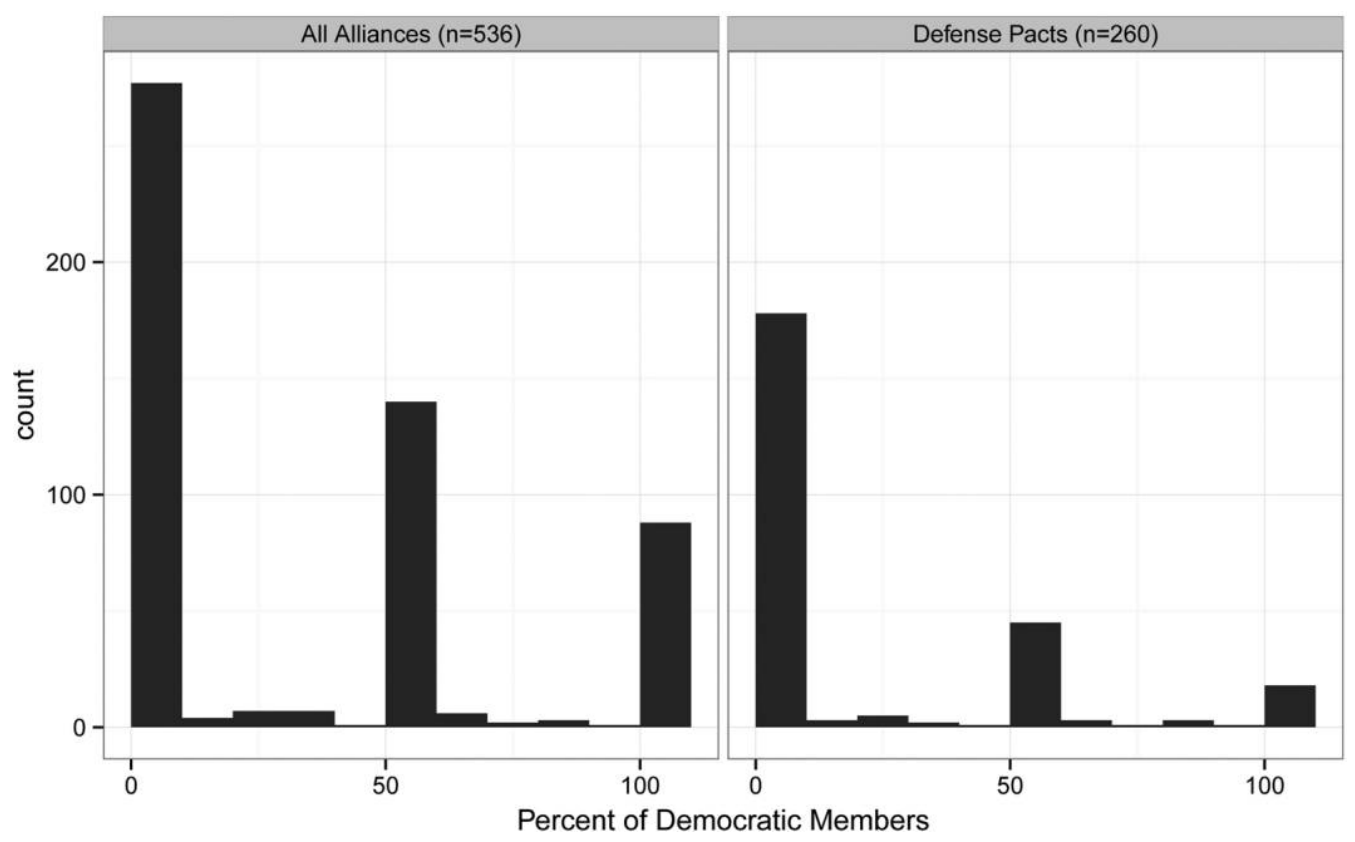

Figure 1. Proportion of original alliance members with democratic political systems

faced by the alliance as the level of threat faced by the most threatened original alliance member. Our results, however, are robust to a measure that captures the mean level of threat faced by the alliance members (see table A.21 in the appendix).

Finally, we control for whether the alliance was formed when at least one state was already involved in war. Alliances formed during wartime are less likely to include solely consultation obligations, and some scholars have argued that the propensity for democratic states to win wars may be associated with their greater propensity to co-ally during war (Choi 2004). This variable comes from the ATOP data set and is coded 1 for 69 cases (13\%).

We also control for the foreign policy portfolio similarity of the alliance members and the number of original alliance members in our analysis of whether a defense pact is invoked only under specific conditions. ${ }^{14}$ As similarity of interests increases, we expect defense pacts to be less likely to be limited to specific conditions since the allies may have less expectation of disagreements in the future. As the number of alliance members increases, we expect that it is more likely that leaders will design commitments limited to specified circumstances.

14. Unlike our analysis of consultation obligations, we do not control for the level of threat faced by the members at the time of alliance formation. It is not straightforward to assess the relationship between levels of threat and the specificity of defense obligations because sometimes the limits are designed to exclude the source of threat from the casus foederis, and some are specifically aimed at addressing the major source of threat.
In addition, we control for two design features in our second analysis. We first control for whether the alliance also includes offensive obligations. Offense pacts are highly likely to be activated only under specific conditions. While the ATOP data set codes conditions on separate obligations separately, it may be that when conditions are specified for the offensive part of an alliance agreement, conditions may be more likely on the defensive aspects also. This variable is coded 1 for 65 of 260 cases (25\%), and the data come from ATOP.

Second, we control for whether the defense pact requires members to consult in the event of a military crisis. In defense pacts that require consultation, members will have less need to place limits on the conditions under which the alliance is invoked because they expect to be able to shape their allies' responses to a crisis during the consultation. Forty-nine percent of the defense pacts in our sample also include consultation obligations; these data come directly from the ATOP data set.

Our dependent variables are dichotomous, and thus we first use simple logit models to estimate our coefficients. Yet while we are interested in evaluating choices regarding design among alliances that are formed, we recognize that leaders must first choose to form an alliance at all. If an alliance is not formed, no design choices are made. This is not a traditional sample selection problem in that the second stage is not a missing value if stage one does not occur; it is logically undefined (Vance and Ritter 2014). Thus, we also employ a two-part model (2PM), sometimes referred to as a hurdle model, to consider the impact of the covariates on 
Table 1. Logit and 2PM Analysis of Alliance Consultation, 1815-2003

\begin{tabular}{|c|c|c|c|c|}
\hline & \multirow{2}{*}{$\begin{array}{c}\text { Logit } 1 \\
\text { Consul } \\
(1)\end{array}$} & \multirow{2}{*}{$\begin{array}{c}\text { Logit } 2 \\
\text { Consul } \\
(2)\end{array}$} & \multicolumn{2}{|c|}{$2 \mathrm{PM} 1$} \\
\hline & & & $\begin{array}{c}\text { Consul } \\
\text { (3) }\end{array}$ & $\begin{array}{c}\text { Alliance } \\
(4)\end{array}$ \\
\hline \multirow[t]{2}{*}{ Proportion of democracies } & $1.80^{* * *}$ & $1.59^{* * *}$ & $1.59^{* * *}$ & .10 \\
\hline & $(.26)$ & $(.26)$ & $(.27)$ & $(.15)$ \\
\hline \multirow[t]{2}{*}{ Similarity of interests } & & $-1.45^{\star \star}$ & $-1.45^{\star \star}$ & .28 \\
\hline & & $(.57)$ & $(.60)$ & $(.37)$ \\
\hline \multirow[t]{2}{*}{ Number of members } & & $-.14^{*}$ & $-.14^{\star *}$ & $.04^{*}$ \\
\hline & & $(.07)$ & $(.07)$ & $(.02)$ \\
\hline \multirow[t]{2}{*}{ Threat level } & & $-1.41^{\star}$ & $-1.41^{\star \star}$ & $-2.20^{\star * \star}$ \\
\hline & & $(.73)$ & $(.65)$ & $(.37)$ \\
\hline \multirow[t]{2}{*}{ War time } & & $-1.12^{\star * *}$ & $-1.12^{\star \star \star}$ & -.04 \\
\hline & & $(.37)$ & $(.40)$ & $(.14)$ \\
\hline \multirow[t]{2}{*}{ Constant } & $-1.41^{* * *}$ & .59 & .59 & $-2.07^{\star * *}$ \\
\hline & $(.14)$ & $(.62)$ & $(.62)$ & $(.39)$ \\
\hline Observations & 536 & 536 & 536 & 5896 \\
\hline
\end{tabular}

Note. Consul $=$ consultation only. Standard errors in parentheses.

${ }^{*} p<.10$.

${ }^{* *} p<.05$.

${ }^{* * *} p<.01$.

the probability an alliance is formed at all (Cragg 1971). The 2PM does not require the exclusion restriction common to Heckman style selection models, and thus it is possible to use the same set of covariates at both stages.

The $2 \mathrm{PM}$ is appropriate for a data generating process that involves first a choice of whether to form an alliance, and conditional on that choice, a choice of design features. But what if a leader simultaneously chooses among forming no alliance, forming a consultation pact, or forming a defense pact? To capture this possibility, we also conduct a multinomial logit analysis for each hypothesis with the additional option of forming no alliance. Due to space concerns, the tables including these multinomial logit results appear in the appendix for this article, but they are discussed in the text of the next section. ${ }^{15}$ Both the $2 \mathrm{PM}$ and multinomial logit analyses require a sample of cases for which no alliance

15. The multinomial logit model is based on the independence of irrelevant alternatives (IIA) assumption. We tested if this assumption is violated and found no evidence of violation. See tables A.24 and A.25 in the appendix. formed. ${ }^{16}$ To generate this sample, we follow the procedure suggested by Poast (2010); we generate a random sample of $k$-adic observations that did not form an alliance and are stratified according to the distribution of our $536 k$-ads that did form an alliance.

\section{EMPIRICAL RESULTS}

The results of our empirical analysis are reported in tables 1 and 2. Table 1 reports our evaluation of hypothesis 1 . The dependent variable in this analysis is a dichotomous variable that codes whether the alliance obligates the members to consultation rather than active assistance. In column 1 we report the results of a simple logit analysis of a specification that includes only our primary independent variable, and in column 2 we report the results of logit analysis

16. Following the recommendation of King and Zeng (2001, 702), we collect 10 times more no alliance observations than alliance observations. As we have 536 alliance observations, the resulting sample size is $536+$ $536 \times 10=5896$. We also conducted analysis using five times more observations, and our interpretation of results was not affected. See tables A.22 through A.25 in the appendix. 
Table 2. Logit and 2PM Analysis of Defense Alliance Conditionality, 1815-2003

\begin{tabular}{|c|c|c|c|c|}
\hline & \multirow{2}{*}{$\begin{array}{c}\text { Logit } 3 \\
\text { Def Con } \\
(1)\end{array}$} & \multirow{2}{*}{$\begin{array}{c}\text { Logit } 4 \\
\text { Def Con } \\
(2)\end{array}$} & \multicolumn{2}{|c|}{ 2PM 2} \\
\hline & & & $\begin{array}{c}\text { Def Con } \\
\text { (3) }\end{array}$ & $\begin{array}{c}\text { Defense } \\
(4)\end{array}$ \\
\hline Proportion of democracies & $\begin{array}{c}.72^{*} \\
(.40)\end{array}$ & $\begin{array}{l}1.00^{* *} \\
(.48)\end{array}$ & $\begin{array}{l}1.00^{* *} \\
(.47)\end{array}$ & $\begin{array}{c}-1.22^{* * *} \\
(.25)\end{array}$ \\
\hline Similarity of interests & & $\begin{array}{r}-1.15^{\star} \\
(.67)\end{array}$ & $\begin{array}{r}-1.15 \\
(.73)\end{array}$ & $\begin{array}{l}1.54^{\star * *} \\
(1.50)\end{array}$ \\
\hline Number of members & & $\begin{array}{l}.11^{\star *} \\
(.05)\end{array}$ & $\begin{array}{l}.11^{*} \\
(.06)\end{array}$ & $\begin{array}{l}.11^{* * *} \\
(.03)\end{array}$ \\
\hline Offense obligation & & $\begin{array}{l}1.54^{* * *} \\
(.33)\end{array}$ & $\begin{array}{l}1.54^{* * *} \\
(.31)\end{array}$ & \\
\hline Consultation obligation & & $\begin{array}{c}-.85^{\star * *} \\
(.29)\end{array}$ & $\begin{array}{c}-.85^{\star * *} \\
(.28)\end{array}$ & \\
\hline Constant & $\begin{array}{c}-.34^{* *} \\
(.15)\end{array}$ & $\begin{array}{l}.24 \\
(.64)\end{array}$ & $\begin{array}{l}.24 \\
(.68)\end{array}$ & $\begin{array}{c}-4.28^{* * *} \\
(.46)\end{array}$ \\
\hline Observations & 260 & 260 & 260 & 5896 \\
\hline
\end{tabular}

Note. Def Con $=$ Defense Conditionality. Standard errors in parentheses.

${ }^{*} p<.10$.

$* * p<.05$.

$* * * p<.01$

including control variables. Columns 3 and 4 present our 2PM, with column 3 showing the effects of the independent variables on the probability an alliance that is formed includes only consultation obligations, while column 4 shows the effects of the independent variables on the probability an alliance is formed at all.

The results in table 1 provide support for hypothesis 1 . Alliances formed by a larger proportion of democracies are more likely to obligate states to future consultation rather than active assistance. This suggests that leaders that expect to experience high costs for violating alliance agreements may commit to obligations that provide them with discretion over the required actions in the event of conflict. In addition, most of our control variables are also statistically significant in the directions we would expect. States are less likely to limit their alliance promises to consultation only when they are involved in a war, when they face a high threat environment, and when they share more similar interests with their alliance partners. On the other hand, contrary to our expectations, as the number of alliance members increases, states appear to be less likely to limit their promises to consultation. Our interpretation of results is not affected by including nonalliance cases, either using the 2PM strategy or a multinomial logit strategy (see table A.24 in the appendix). The results from the multinomial logit show that $k$-ads with a higher proportion of democracies are more likely to form consultation pacts rather than other types of alliances, less likely to form other types of alliance (e.g., defense pacts, offense pacts, and neutrality pacts) than to form no alliance, and more likely to form consultation pacts than no alliance.

Figure 2 shows the substantive effect of our primary independent variable, proportion of democracies in an alliance, on the likelihood that alliances obligate member states only to consultation. This figure is created using the information in column 3 of table 1 (the second stage of our $2 \mathrm{PM}$ results). We calculate predicted probabilities for three different values of percent of democracies in an alliance: $0 \%$, $50 \%$, and $100 \%$, while holding the values of the control variables at their mean value. Note that these three values of the primary independent variable are the three most frequent values observed in our data. We obtain uncertainty estimates for the predictions following the procedures described by King, Tomz, and Wittenburg (2000). The three horizontal line segments located near the bottom part of the density plots indicate whether the differences between the predicted probabilities are statistically significant at the $95 \%$ confidence level.

When an alliance is formed by nondemocracies, the probability that it obligates members to future consultation is only 0.20 (shown in the white density plot at the left of the figure). When we increase the value of the proportion of democracy to $50 \%$ (holding everything else constant), the predicted prob- 


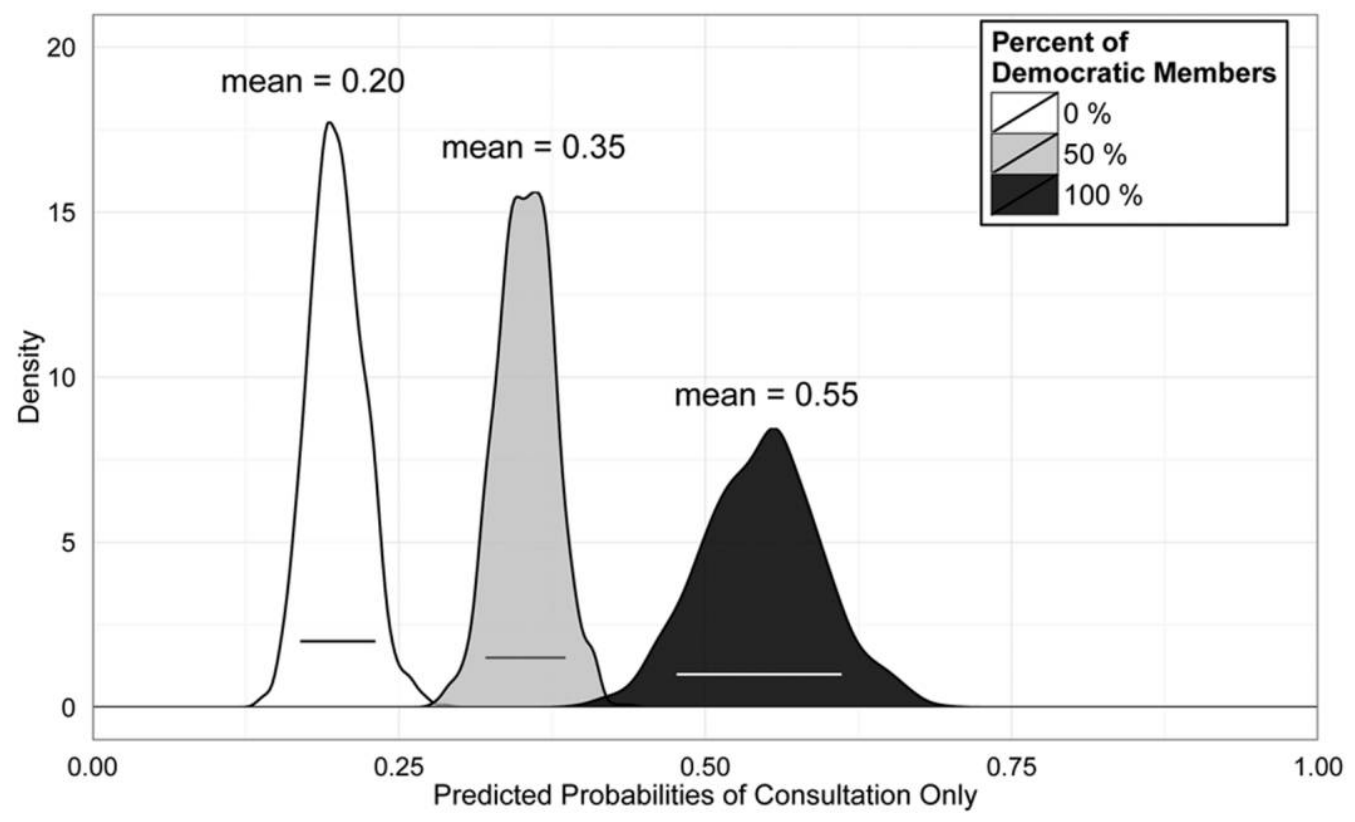

Figure 2. Predicted probability that an alliance includes only consultation obligations for alliances with different proportions of democratic members

ability increases to 0.35 (shown in the light gray density plot in the middle of the figure). When all the states forming an alliance are democracies, the predicted probability that the alliance will commit the states only to future consultation is 0.55 (shown in the dark gray density plot at the right of the figure). The differences between these three probability estimates are highly significant.

Table 2 reports our evaluation of hypothesis 2 . The dependent variable for this analysis is a dichotomous variable that codes whether the defense pact specifies limits to the conditions under which the defensive obligation is invoked. Again, column 1 reports results of a logit analysis of a model specification that includes only our primary independent variable, column 2 reports results of the logit analysis of a model specification including our control variables, and columns 3 and 4 present a $2 \mathrm{PM}$.

The results in table 2 provide support for hypothesis 2 , although the size of the coefficient and its level of confidence both increase in the models that include the control variables. Defense pacts formed by a larger proportion of democracies are more likely to specify limits to the conditions under which defensive obligations are invoked. This finding is commensurate with our argument that leaders who expect to experience high costs for violating alliance agreements may be very specific in committing to actions that they are likely to be willing to take. The results in table 2 also provide some support for our expectations about our control variables. States that share more similar interests with their alliance partners are less likely to limit the conditions under which their defense pacts are invoked in the logit and multinomial logit model (see table A.25 in the appendix), but this variable does not reach conventional levels of statistical significance in the 2PM. As the number of original alliance members increases, however, the conditions under which a defense pact may be invoked are more likely to be limited. Alliances that include both defensive and offensive obligations are more likely to include limits to the conditions under which the defensive obligation is invoked. Finally, when states include consultation obligations in their defense pacts they are less likely to include limits to the conditions under which the defensive obligation is invoked.

Figure 3 shows the substantive effect of the proportion of original members with democratic political systems on the likelihood that defensive alliances have specific limits on the conditions under which they are invoked. Once again, we calculate predicted probabilities for three different values of democracy proportion. These estimates are based on column 3 of table 2 while holding the values of the control variables at their mean value. As in our earlier figure, the three horizontal line segments located near the bottom part of the densities indicate whether the differences between the predicted probabilities are statistically significant at the $95 \%$ confidence level. The line segments show that all of the predicted probabilities are significantly different from one another except the predicted probability of defense pact conditionality when the percent of democracies is $50 \%$ and when it is $100 \%$. Therefore, our results suggest that defense pacts formed by all democracies are more likely to include specific conditions than ones formed by all nondemocracies, and defense pacts formed by $50 \%$ democracies are more likely to include specific 


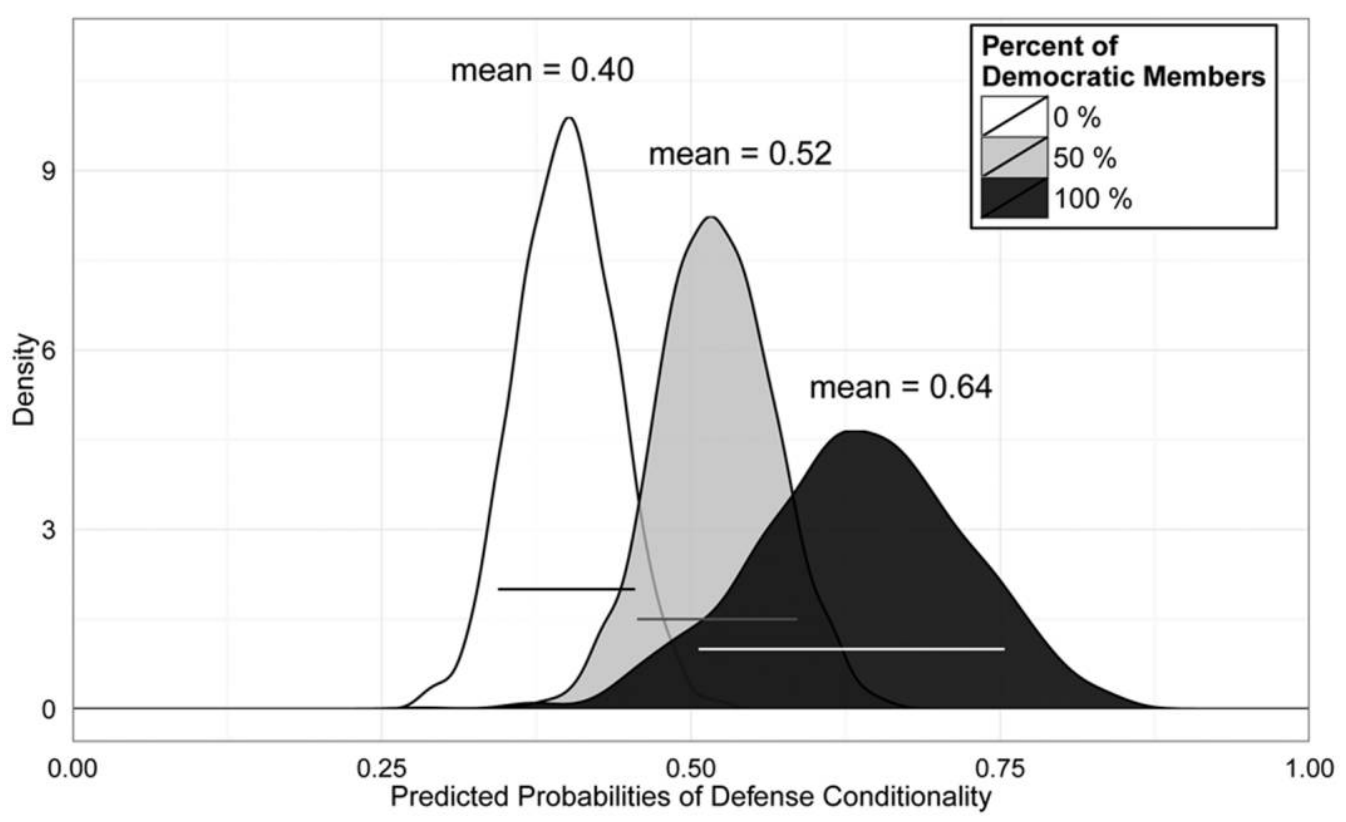

Figure 3. Predicted probability that defense obligations are conditional for alliances with different proportions of democratic members

conditions than ones formed by all nondemocracies. Both results provide support for hypothesis 2 . Given that our previous analysis shows that democracies are less likely to form defense pacts than consultation pacts, it is not surprising that there are a small number of defense pacts that include only democratic members, and thus that there is substantial uncertainty around our predictions about these cases.

The results reported in tables 1 and 2 and figures 2 and 3 provide support for additional implications of a body of research on the effect of domestic politics on international relations. While past research has demonstrated that regime type affects the propensity of states to fulfill their international agreements, we suggest that regime type also affects the willingness of states to commit to broad and deep cooperation. What is an advantage for democratic states in making their commitments credible (and thus attracting partners to their cooperative endeavors) may simultaneously make democratic leaders reluctant to join international commitments that require particularly broad or deep cooperation, except when they are very confident that fulfilling the agreement will be in their future interest. The tendency noted by Downs, Rocke, and Barsoom (1996) for states to commit to agreements that they know they can fulfill may be particularly applicable to democracies.

\section{IMPLICATIONS FOR UNDERSTANDING INTERNATIONAL COOPERATION}

Our work suggests that states that expect high costs from violating commitments may design cooperative agreements in ways that limit their future obligations; they may be more reluctant to form "deep" agreements. When such states do form deep agreements, however, one can deduce that they have little uncertainty about their willingness to fulfill the agreement if the agreement is invoked. Combined, this suggests two things: (1) it may be very difficult to observe instances in which a state is constrained by a past agreement, and (2) screening effects are stronger for states that have a high probability of constraint. It may not be appropriate to ask whether agreements screen or constrain (see, e.g., Simmons and Hopkins 2005; von Stein 2005). Agreements screen when they have the potential to constrain, and the better they screen, the less easy it is to observe constraint.

Consider, for instance, an ongoing debate about whether or not democracies make more reliable alliance partners. There appears to be consistent evidence that alliances involving democratic states last longer and are less likely to be terminated in violation of their terms (Bennett 1997; Gaubatz 1996; Leeds, Mattes, and Vogel 2009; Leeds and Savun 2007). On the other hand, there is at least some debate about whether democracies are more likely to assist their alliance partners in wars and militarized disputes. Leeds (2003a) finds that democracies are less likely to violate their commitments in wartime, whereas Gartzke and Gleditsch (2004) argue that democracies are actually more likely to violate their alliance commitments during wartime. A major difference between the two research designs is that Leeds (2003a) judges reliability by whether or not the alliance member joined a war in which the specific alliance obligations were invoked. Cases in which the alliance treaty did not specify that a partner was required to join a conflict were dropped from the analysis 
on the basis that they provide no information about whether the alliance member violated the terms of the treaty. In their main analysis, however, Gartzke and Gleditsch (2004) do not take into account the specific terms of the treaty. ${ }^{17}$ Instead, they analyze whether each member of a defense pact joined any war in which one of its allies was involved. Since democracies are more likely to place limits on their commitments, an analysis that does not take into account such limits is likely to come to different conclusions about democratic reliability than one that does take into account the care states take in crafting their treaties.

The conclusions for democratic reliability, then, may be more nuanced than previously reported. On one hand, it seems likely that when one takes into account the specific promises made in a treaty, democracies may be more likely to fulfill their commitments. At the same time, this is due not only to the costs that democracies experience from violating their past promises but also to the propensity for democracies to make very careful commitments and avoid obligating themselves to participating in conflicts in which they may not have an interest. The effect is likely driven both by constraint and by selection.

\section{CONCLUSIONS AND DIRECTIONS FOR FUTURE RESEARCH}

Recent international relations scholarship emphasizes the high costs that democratic leaders pay for violating past commitments. This emphasis has enhanced our understanding of crisis bargaining as well as the emergence and success of international cooperation. We build on this research by suggesting that the high costs suffered by democratic leaders for violating past commitments can also help us understand the design of agreements. Democratic leaders foresee these high costs and are careful to design agreements that limit their risks of paying them.

We evaluate this argument in the context of military alliance design. If democratic leaders experience relatively high costs for violating alliance agreements, then they should adopt design features that reduce their chances of being unable or unwilling to fulfill their alliance commitments. We suggest there are two primary strategies that democratic leaders might choose between in designing their alliances for this purpose.

17. Gartzke and Gleditsch also report an analysis with unpublished ATOP data (an incomplete update) in which they find a positive correlation between democracy and alliance violation (2004, 789). This relationship does not exist in that data set using the same research design as Leeds (2003a). In an unpublished conference paper using the same incomplete update, Leeds and Gigliotti-Labay (2003) report when other factors found to be important for predicting alliance violation are included in the model, there is no statistically significant relationship between democracy and alliance violation.
First, they might make flexible commitments that do not commit them to specific future action. Second, they might be very clear about the specific conditions under which the alliance is invoked. By analyzing data on alliance treaties and regime type from 1815 to 2003 we find support for both hypotheses.

This evidence has significant implications for understanding the relationship between regime type and international cooperation. On one hand, the domestic costs associated with breaking international commitments makes democratic states reliable treaty partners. On the other hand, the same domestic costs can make democratic states wary of engaging in agreements requiring broad and/or deep cooperation. Future research linking domestic political institutions with international cooperation will benefit from paying attention to both of these effects.

In addition, this study should be of interest to scholars studying the effects of international agreements on behavior in all areas. For example, in the human rights issue area, scholars have noted that on one hand, some strong proponents of human rights like the United States have been reluctant to sign agreements that their policies comply with. On the other hand, there appear to be a set of states willing to sign human rights agreements and violate them egregiously. Those states that believe the agreements are more likely to be enforced through domestic processes are more reluctant to sign, whereas states that are less wary of costs of noncompliance sign agreements more readily (e.g., Simmons 2009). In both the human rights case and in our alliance case, screening appears to be endogenous to expectations of constraint. This significantly complicates efforts to separate the screening and constraining effects of agreements and suggests that the two should be seen as complements to one another rather than alternative paths of influence. Our research suggests that we can isolate at least some observable factors that influence constraining (and, in turn, screening) effects, which should facilitate future research.

Finally, our research supports the view that screening happens not only through the decision to form an agreement or not but also through design decisions about the scope and flexibility of agreements. While paying attention to the design decisions that leaders make in formulating their promises does increase the complexity of research, it also offers an important payoff in understanding the role international law can play. Such studies have the potential to provide important policy recommendations about effective agreement design.

\section{ACKNOWLEDGMENTS}

The authors thank Annie Anderson, Tiffany Barnes, Scott Gartner, Melissa Griffith, Naoko Matsumura, Michaela 
Mattes, Steven Miller, Paul Poast, Justin Wedeking, and Ahra $\mathrm{Wu}$ for helpful suggestions on previous drafts.

\section{REFERENCES}

Allee, Todd L., and Paul K. Huth. 2006. "Legitimizing Dispute Settlement: International Legal Rulings as Domestic Political Cover." American Political Science Review 100 (2): 219-34.

Baltzly, Alexander, and A. William Salamone. 1950. Readings in TwentiethCentury European History. New York: Appleton-Century-Crofts.

Bennett, D. Scott. 1997. "Testing Alternative Models of Alliance Duration, 1816-1984." American Journal of Political Science 41 (3): 846-78.

Benson, Brett V. 2012. Constructing International Security: Alliances, Deterrence, and Moral Hazard. New York: Cambridge University Press.

Cheibub, Jose Antonio, Jennifer Gandhi, and James Raymond Vreeland. 2010. "Democracy and Dictatorship Revisited." Public Choice 143 (1-2): 67-101.

Choi, Ajin. 2004. "Democratic Synergy and Victory in War, 1816-1992." International Studies Quarterly 48 (3): 663-82.

Cragg, John G. 1971. "Some Statistical Models for Limited Dependent Variables with Application to the Demand for Durable Goods." Econometrica 39 (5): 829-44.

Crescenzi, Mark J. C., Jacob D. Kathman, Katja B. Kleinberg, and Reed M. Wood. 2012. "Reliability, Reputation, and Alliance Formation." International Studies Quarterly 56 (2): 259-74.

Croco, Sarah E. 2011. "The Decider's Dilemma: Leader Culpability, War Outcomes, and Domestic Punishment." American Political Science Review 105 (3): 457-77.

Dixon, William J. 1993. "Democracy and the Management of International Conflict." Lournal of Conflict Resolution 37 (1): 42-68.

Downs, George W., David M. Rocke, and Peter N. Barsoom. 1996. "Is the Good News about Compliance Good News about Cooperation?" International Organization 50 (3): 379-406.

Fang, Songying, Jesse C. Johnson, and Brett Ashley Leeds 2014. "To Concede or To Resist? The Restraining Effect of Military Alliances." International Organization. http://dx.doi.org/10.1017/S0020818314000137.

Fearon, James D. 1994. "Domestic Political Audiences and the Escalation of International Disputes." American Political Science Review 88 (3): $577-92$.

Fearon, James D. 1997. "Signaling Foreign Policy Interests: Tying Hands vs. Sinking Costs." Lournal of Conflict Resolution 41 (1): 68-90.

Gartzke, Erik, and Kristian Gleditsch. 2004. "Why Democracies May Actually Be Less Reliable Allies." American Journal of Political Science 48 (4): 775-95.

Gaubatz, Kurt Taylor. 1996. "Democratic States and Commitment in International Relations." International Organization 50 (1): 109-39.

Gent, Stephen E., and Megan Shannon. 2011. "Decision Control and the Pursuit of Binding Conflict Management: Choosing the Ties that Bind." Journal of Conflict Resolution 55 (5): 710-34.

Gibler, Douglas M. 2008. “The Costs of Reneging: Reputation and Alliance Formation." Iournal of Conflict Resolution 52 (3): 426-54.

Hafner-Burton, Emilie M., Laurence R. Helfer, and Christopher J. Fariss. 2011. "Emergency and Escape: Explaining Derogations from Human Rights Treaties." International Organization 65:673-707.

Johnson, Jesse C., and Brett Ashley Leeds. 2011. "Defense Pacts: A Prescription for Peace?" Foreign Policy Analysis 7 (1): 45-65.

Kelley, Judith. 2007. "Who Keeps International Commitments and Why? The International Criminal Court and Bilateral Nonsurrender Agreements." American Political Science Review 101 (3): 573-89.

Kim, Tongfi. 2011. "Why Alliances Entangle but Seldom Entrap States." Security Studies 20 (3): 350-77.
King, Gary, Michael Tomz, and Jason Wittenberg. 2000. "Making the Most of Statistical Analyses: Improving Interpretation and Presentation." American Journal of Political Science 44 (2): 347-61.

King, Gary, and Langche Zeng. 2001. "Explaining Rare Events in International Relations.” International Organization 55:693-715.

Koremenos, Barbara. 2005. "Contracting around International Uncertainty." American Political Science Review 99 (4): 549-65.

Leeds, Brett Ashley. 1999. "Domestic Political Institutions, Credible Commitments, and International Cooperation." American Journal of Political Science 43 (4): 979-1002.

Leeds, Brett Ashley. 2003a. "Alliance Reliability in Times of War: Explaining State Decisions to Violate Treaties." International Organization 57 (4): 801-27.

Leeds, Brett Ashley. 2003b. "Do Alliances Deter Aggression? The Influence of Military Alliances on the Initiation of Militarized Interstate Disputes." American Journal of Political Science 47 (3): 427-39.

Leeds, Brett Ashley. 2005. "Alliance Treaty Obligations and Provisions (ATOP) Codebook." http://atop.rice.edu/download/ATOPcdbk.pdf (accessed February 26, 2013).

Leeds, Brett Ashley, and Jennifer Gigliotti-Labay. 2003. "You Can Count on $\mathrm{Me}$ ? Democracy and Alliance Reliability." Presented at the annual meeting of the American Political Science Association, Philadelphia, August 28-31. http://www.allacademic.com/meta/p64472_index.html (accessed March 8, 2014).

Leeds, Brett Ashley, and Michaela Mattes. 2007. "Alliance Politics during the Cold War: Aberration, New World Order, or Continuation of History?" Conflict Management and Peace Science 24 (3): 183-99.

Leeds, Brett Ashley, Michaela Mattes, and Jeremy S. Vogel. 2009. "Interests, Institutions, and the Reliability of International Commitments." American Journal of Political Science 53 (2): 461-76.

Leeds, Brett Ashley, Jeffrey M. Ritter, Sara McLaughlin Mitchell, and Andrew G. Long. 2002. "Alliance Treaty Obligations and Provisions." International Interactions 28 (2): 237-60.

Leeds, Brett Ashley, and Burcu Savun. 2007. "Terminating Alliances: Why Do States Abrogate Agreements?” Lournal of Politics 69 (4): 1118-32.

Marshall, Monty G., Keith Jaggers, and Ted Robert Gurr. 2012. Polity IV Project: Dataset Users' Manual. College Park: University of Maryland. http://www.systemicpeace.org/inscr/p4manualv2012.pdf (accessed June 2015).

Mattes, Michaela. 2012. "Democratic Reliability, Precommitment of Successor Governments, and the Choice of Alliance Commitment." International Organization 66 (1): 153-72.

Mattes, Michaela, and Mariana Rodriguez. 2014. "Non-Democracies and International Cooperation." International Studies Quarterly 58 (3): 527-38.

Mattes, Michaela, and Greg Vonnahme. 2010. "Contracting for Peace: Do Nonaggression Pacts Reduce Conflict?" Journal of Politics 72 (4): 925-38.

McGillivray, Fiona, and Alastair Smith. 2008. Punishing the Prince: A Theory of Interstate Relations, Political Institutions, and Leader Change. Princeton, NJ: Princeton University Press.

Mitchell, Sara McLaughlin, and Paul R. Hensel. 2007. "International Institutions and Compliance with Agreements." American Journal of Political Science 51 (4): 721-37.

Moravscik, Andrew. 2000. "The Origins of Human Rights Regimes: Democratic Delegation in Postwar Europe." International Organization 54 (2): 217-52.

Morrow, James D. 1991. "Alliances and Asymmetry: An Alternative to the Capability Aggregation Model of Alliances." American Journal of Political Science 35 (4): 904-33.

Morrow, James D. 1994. "Alliances, Credibility, and Peacetime Costs." Journal of Conflict Resolution 38 (2): 270-97. 
Morrow, James D. 2007. "When Do States Follow the Laws of War?" American Political Science Review 101 (3): 559-72.

Poast, Paul. 2010. "(Mis)Using Dyadic Data to Analyze Multilateral Events.” Political Analysis 18 (4): 403-25.

Rosendorff, B. Peter, and Helen V. Milner. 2001. "The Optimal Design of International Trade Institutions: Uncertainty and Escape." International Organization 55 (4): 829-57.

Schultz, Kenneth A. 1999. "Do Democratic Institutions Constrain or Inform? Contrasting Two Institutional Perspectives on Democracy and War." International Organization 53 (2): 233-66.

Signorino, Curtis S., and Jeffrey M. Ritter. 1999. "Tau-b or Not Tau-b: Measuring the Similarity of Foreign Policy Positions." International Studies Quarterly 43 (1): 115-44

Simmons, Beth A. 2002. "Capacity, Commitment, and Compliance: International Institutions and Territorial Disputes." Lournal of Conflict Resolution 46 (6): 829-56.

Simmons, Beth A. 2009. Mobilizing for Human Rights: International Law in Domestic Politics. New York: Cambridge University Press.

Simmons, Beth A., and Daniel J. Hopkins. 2005. "The Constraining Power of International Treaties: Theory and Method." American Political Science Review 99 (4): 623-31.

Smith, Alastair. 1995. "Alliance Formation and War." International Studies Quarterly 39 (4): 405-25.

Smith, Alastair. 1998a. "Extended Deterrence and Alliance Formation." International Interactions 24 (4): 315-43.

Smith, Alastair. 1998b. "International Crises and Domestic Politics." American Political Science Review 92 (3): 623-38.
Snyder, Glenn H. 1984. "The Security Dilemma in Alliance Politics." World Politics 36 (4): 461-95.

Snyder, Glenn H. 1997. Alliance Politics. Ithaca, NY: Cornell University Press.

Snyder, Jack, and Erica D. Borghard. 2011. “The Cost of Empty Threats: A Penny, Not a Pound." American Political Science Review 105 (3): 43756.

Tomz, Michael. 2008. "Reputation and the Effect of International Law on Preferences and Beliefs." Working Paper, Stanford University, San

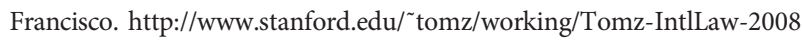
-02-11a.pdf (accessed June 2013).

Tomz, Michael, and Jessica L. P. Weeks. 2015. "Military Alliances and Public Support for War." Working Paper, Stanford University, San Francisco. http://web.stanford.edu/ tomz/working/TomzWeeks-Alliances -2015-02-14.pdf (accessed April 15, 2015).

United Nations. 1955. UN Treaty Series. New York: United Nations.

Uzonyi, Gary, Mark Souva, and Sona N. Golder. 2012. "Domestic Institutions and Credible Signals." International Studies Quarterly 56 (4): 765-76.

Vance, Colin, and Nolan Ritter. 2014. "Is Peace a Missing Value or a Zero? On Selection Models in Political Science." Journal of Peace Research 51 (4): 528-40.

Von Stein, Jana. 2005. "Do Treaties Constrain or Screen? Selection Bias and Treaty Compliance." American Political Science Review 99 (4): 611-22.

Weeks, Jessica L. 2008. “Autocratic Audience Costs: Regime Type and Signaling Resolve.” International Organization 62 (1): 35-64. 